\title{
The Relationship between Body Mass Index (BMI) and Gleason Score of Indonesian Prostate Cancer Men in Hasan Sadikin General Hospital
}

\author{
Fauzan Abdurrahman*, Sri Suryanti **, Aaron T Sihombing*** \\ *Faculty of Medicine Padjadjaran University \\ ** Department of Pathological Anatomy \\ Faculty of Medicine Padjadjaran University - Dr. Hasan Sadikin General Hospital \\ ***Department of Urology \\ Faculty of Medicine Padjadjaran University - Dr. Hasan Sadikin General Hospital \\ Jl. Prof. Eyckman No. 38, Bandung, 40161 \\ Email :fabd2203@gmail.com
}

\begin{abstract}
Prostate adenocarcinoma is the second most commonly diagnosed cancer and the sixth most common cause of cancer-related mortality among men worldwide.The risk of high grade prostate cancer in Asia in relation to BMI is unclear. The objective of this study is to analyze the relationship between BMI and Gleason score in Indonesian prostate adenocarcinoma (PCa) patients.This is a cross sectional study conducted in Hasan Sadikin General Hospital Bandung. The data is obtained from secondary data soure of prostate adenocarcinoma patients'medical records in Hasan Sadikin General Hospital. The data is analyzed by using Chi square and Spearman correlation test. The data is collected from 95 Indonesian patients with PCa. The result shows that 78 patients are within normal BMI range, and 41 patients 52.6\%) of them has high level Gleason score, whereas 17 patients are within high BMI range, and high Gleason score is found in 11 patients $(64.7 \%)$ of them $\left(P=0.362 ; r_{s}=0.094\right)$. This study concludes that there is no relation between BMI in Indonesian PCa and Gleason score.
\end{abstract}

Keywords : prostate adenocarcinoma (PCa); BMI; Gleason score; prostate malignancy 


\title{
Hubungan Body Mass Index (BMI) dan Gleason Score pada Penderita Keganasan Prostat di Rumah Sakit Umum Hasan Sadikin
}

\author{
Fauzan Abdurrahman*, Sri Suryanti **, Aaron T Sihombing*** \\ *Fakultas Kedokteran Universitas Padjadjaran \\ **Departemen Patologi Anatomi Fakultas Kedokteran \\ Universitas Padjadjaran - Rumah Sakit Umum Dr. Hasan Sadikin \\ ***Departemen Urologi Fakultas Kedokteran \\ Universitas Padjadjaran - Rumah Sakit Umum Dr. Hasan Sadikin \\ J1. Prof. Eyckman No. 38, Bandung, 40161 \\ Email : fabd2203@gmail.com
}

\begin{abstract}
Abstrak
Adenokarsinoma prostat adalah kanker kedua tersering dan penyebab kematian ke enam terbanyak terkait kanker pada pria di seluruh dunia. Hubungan risiko dari keganasan kanker prostat di Asia dengan indeks massa tubuh (IMT) belum jelas diketahui. Tujuan dari penelitian ini adalah untuk mengetahui hubungan antara IMT dan skor Gleason pada pasien adenokarsinoma prostat di Indonesia. Penelitian ini merupakan penelitian dengan desain potong lintang, dilakukan di Rumah Sakit Umum Hasan Sadikin Bandung. Data yang digunakan merupakan data sekunder yang diambil dari rekam medis pasien adenokarsinoma prostat di Rumah Sakit Umum Hasan Sadikin. Data dianalisis menggunakan uji Chi kuadrat dan uji korelasi Spearman. Kami mengumpulkan data dari 95 subjek penelitian dan mendapat hasil 78 pasien dalam kisaran IMT normal. Dari kelompok tersebut 41 orang $(52,6 \%)$ berada di skor Gleason tinggi. 17 pasien berada dalam rentang IMT tinggi, dan skor Gleason tinggi ditemukan pada 11 pasien $(64,7 \%)$ pada kelompok tersebut $(\mathrm{P}=0,362 ; \mathrm{rs}=0,094)$. Kami menyimpulkan tidak ada hubungan antara IMT pada pasien adenokarsinoma prostat dan skor Gleason di Indonesia.
\end{abstract}

Kata Kunci: adenokarsinoma prostat; IMT; skor Gleason; keganasan prostat 


\section{Research Article}

\section{Introduction}

Prostate adenocarcinoma is the second most commonly diagnosed cancer and the sixth most common cause of cancer-related mortality among men worldwide. ${ }^{1-3}$ It is the most common threat of cancer on male in many European countries, and there was the highest incidence of cancer on males in the USA. ${ }^{2,4-6}$ People with prostate adenocarcinoma in Europe based on European Cancer Observatory (ECO) in 2012 were 417.000 patients and in USA were 180.890 patients. ${ }^{5,6}$ Although much lower than that in Western countries and USA, the incidence of prostate cancer in the Asia has been rapidly increasing over the past few decades, including Indonesia. $^{7-9}$ People with prostate adenocarcinoma in Asia based on Globocan in 2008 were 122.000 patients. ${ }^{10}$ In Indonesia based on Indonesian Society of Urologic Oncology in 2011 there were 971 patients. ${ }^{8,9}$

The epidemiological studies have shown that obesity has been associated with increased risk and death of multiple cancers, including prostate cancer. ${ }^{3,11,12}$ The WHO estimates that today's obesity worldwide is doubled compared to $1980 .{ }^{13,14}$ In 2014 , more than 1.9 billion people in world population were overweight $\left(\mathrm{BMI} \leq 25 \mathrm{~kg} / \mathrm{m}^{2}\right.$ ). Of these over 600 million were obese $\left(\mathrm{BMI}>30 \mathrm{~kg} / \mathrm{m}^{2}\right) .{ }^{14}$ In Europe, the prevalence of overweight and obesity continues to rise, and current levels are comparable with those of the USA 15 year ago. ${ }^{3}$ Based on European Health Interview Survey (EHIS) in 2008, the prevalence was increased to 69.3\%, meanwhile in the USA based on National Center for Health Statistics (NCHS) in 2014, the prevalence was increased to 36.5\%. ${ }^{15,16}$ Although much lower than that in Western countries and USA, in Asia based on Western Pacific Regional Office of WHO (WPRO) in 2013 the prevalence was increased to $27.9 \% .{ }^{17}$ In Indonesia, the prevalence of overweight and obesity continue to rise. Based on Ministry of Health of the Republic Indonesia in 2007, the prevalence was $18.8 \%$ and increased to $26.6 \%$ in 2013 based on Basic Health Research (RISKESDAS). ${ }^{18,19}$

High level of body mass index (BMI) is suspected to have a relationship with high level of Gleason score of prostate cancer in the Western countries, USA, and China. Gleason score is a scoring system to categorize the degree of malignancy of prostate adenocarcinoma. ${ }^{20,21} \mathrm{BMI}$ has been also associated with higher recurrence rates after radiotherapy treatment, it was suggesting that obesity may influence prostate cancer aggressiveness and progression. ${ }^{21}$ Indeed, among Asian men, several studies reported that a higher BMI had either positive or negative effects on the risk of prostate cancer (PCa) and high-grade PCa (HGPCa). ${ }^{22}$ Based on the above statement, the allegations may be different from Indonesian prostate cancer patients. The objective of this study is to find relationship between BMI and Gleason score of prostate cancer on Indonesian prostate adenocarcinoma patients in Hasan Sadikin General Hospital during 
Research Article

period of $2012-2016$.

\section{Methods}

A cross sectional study was conducted in Hasan Sadikin General Hospital and used retrospective data as the sampling method. We used secondary data taken from medical records of prostate adenocarcinoma patients in Hasan Sadikin General Hospital during period of 2012 2016. Ethical approval was obtained from the Ethical Committee of Penelitian Kesehatan Fakultas Kedokteran Universitas Padjadjaran and Hasan Sadikin General Hospital 480/UN6.C.10/PN/2017.

We categorize the subjects into two groups; normal and high $\left(\mathrm{BMI}>25 \mathrm{~kg} / \mathrm{m}^{2}\right)$. Normal group consists of normal and underweight $\left(\mathrm{BMI}<18.5 \mathrm{~kg} / \mathrm{m}^{2}\right)$ due to data limitation and also to simplify data processing. High level group consists of overweight (BMI $>25 \mathrm{~kg} / \mathrm{m}^{2}$ ) and obesity $\left(\mathrm{BMI}>30 \mathrm{~kg} / \mathrm{m}^{2}\right)$. The grouping of Gleason score in this study were low level $(\leq 7)$ and high level $(8-10)$.

Patient's medical records with diagnosis of prostate adenocarcinoma from $2012-2016$ recorded in Department of Pathological Anatomy and Department of Urology. There were 95 patients selected to be sampled. The inclusion criteria was Indonesian race on prostate adenocarcinoma patients and the data were excluded due to incomplete medical records, in particular there were no results of weight and height measurement of prostate adenocarcinoma patients in Hasan Sadikin General Hospital.

Data was analyzed using Chi square test to see the independence of 2 variables and Spearman correlation test (due to abnormal distribution) to see the correlation between BMI and Gleason.

\section{Results}

We collected data from the total number of 184 cases of prostate adenocarcinoma that were reported in this study period. In total, 89 data were excluded due to its incompleteness. There were 95 Indonesian PCa patients included in this study. Seventy eight patients is in normal BMI range, 41 patients $(52.6 \%)$ of them have high level Gleason score. Seventeen patients are within high BMI range, and 11 patients (64.7\%) of them have high level Gleason score (see table 1 and figure 1). 
Table 1 Crosstabulation of Gleason score and BMI of Prostate Adenocarcinoma Patients

\begin{tabular}{cllccc}
\hline \multicolumn{5}{c}{ Crosstabulation of Prostate Adenocarcinoma Patients in R.S. Hasan Sadikin Bandung } \\
\hline & & \multicolumn{2}{c}{ Gleason score } & Total \\
& & & $\leq 7$ & $8-10$ & \\
\hline BMI $^{\mathrm{a}}$ & Normal & $\mathrm{N}$ & 37 & 41 & 78 \\
& & Percentages & $47.4 \%$ & $52.6 \%$ & $100.0 \%$ \\
\cline { 2 - 5 } & High $\left(>25 \mathrm{~kg} / \mathrm{m}^{2}\right)$ & $\mathrm{N}$ & 6 & 11 & 17 \\
& & Percentages & $35.3 \%$ & $64.7 \%$ & $100.0 \%$ \\
\hline
\end{tabular}

Information

a. $\mathrm{BMI}=$ Body mass index.

b. Malignancy of Gleason score $=\leq 7$ (low) and 8-10 (high).

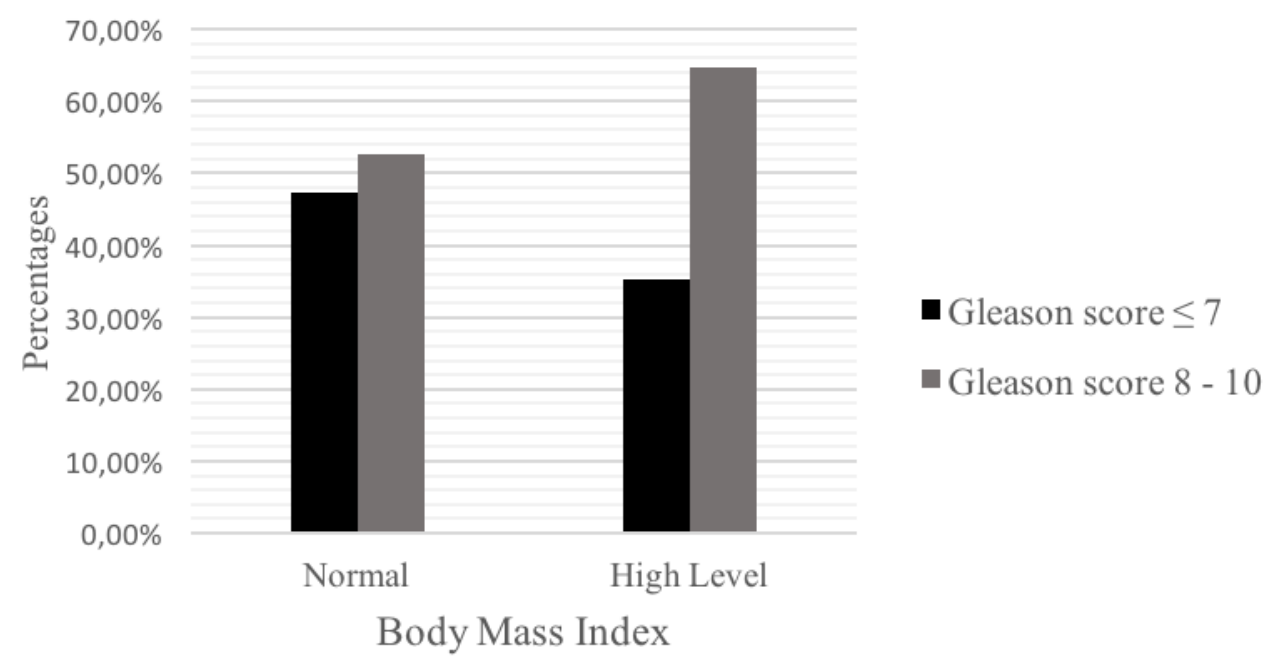

Figure 1 Distribution of Gleason score and BMI of prostate adenocarcinoma patients in Hasan Sadikin General Hospital Bandung.

The Chi square test results showed $\mathrm{p}$ value of $0.362(P>0,05)$ which means there were no relation between BMI and Gleason score (see table 2). The correlation test result show $\mathrm{p}$ value of $0.367(P>0,05)$ which means there were no correlation between BMI and Gleason score. The coefficient correlation results showed $r_{s}=0.025\left(r_{s}<0.5\right)$ which means the correlation were very weak between the two variables (see table 3 ). 
Table 2 The Independence Test of The Relationship between BMI and Gleason Score

\begin{tabular}{lrrrrr}
\hline \multicolumn{7}{c}{ Chi-Square Test } \\
\hline & Value & df & $\begin{array}{c}\text { Asymptotic Significance }(2 \\
- \text { sided })\end{array}$ & $\begin{array}{c}\text { Exact sig. } \\
(2-\text { sided })\end{array}$ & $\begin{array}{c}\text { Exact sig. } \\
(1-\text { sided })\end{array}$ \\
\hline Pearson Chi - Square $_{\text {Continuity Correction }}^{\mathrm{b}}$ & $.831^{\mathrm{a}}$ & 1 & .362 & \\
Likelihood Ratio $^{\text {N of Valid Cases }}$ & .413 & 1 & .521 & \\
\hline
\end{tabular}

Information

a. 0 cells $(0.0 \%)$ have expected count less than 5 . The minimum expected count is 7.69

b. Computed only for a $2 \times 2$ table

Table 3 Correlation between BMI and Gleason Score of Prostate Adenocarcinoma Patients in Hasan Sadikin General Hospital.

\begin{tabular}{llrr}
\hline & Variable & BMI & \multicolumn{2}{c}{ Gleason score } \\
\hline $\mathrm{BMI}^{\mathrm{b}}$ & $\mathrm{r}_{\mathrm{s}}{ }^{\mathrm{a}}$ & 1.000 & .094 \\
& Sig. $(2$ - tailed $)$ &. & .367 \\
Gleason score & $\mathrm{N}$ & 95 & 95 \\
& $\mathrm{r}_{\mathrm{s}}$ & .094 & 1.000 \\
& Sig. $(2-$ tailed $)$ & .367 & 95 \\
& $\mathrm{~N}$ & 95 & 95 \\
\hline
\end{tabular}

Information

a. $r_{\mathrm{s}}=$ Correlation coefficient of Spearman .

b. $\mathrm{BMI}=$ Body mass index.

\section{Discussion}

There are many etiology of PCa, such as infection, heredity, smoking, and obesity. ${ }^{13}$ One possible link in the relationship between obesity and prostate cancer (PCa) progression is inflammation. ${ }^{13}$ Obesity produces a state of systemic chronic low-grade inflammation that can contribute to a number of chronic diseases, including advanced PCa. ${ }^{23,24}$ Inflammation can cause metabolic changes, such as insulin resistance. ${ }^{3,13}$ Increased insulin levels in body can make upregulation of the IGF-1 receptor that accompanies the transition of androgen-dependent cell lines to androgen independence, and IGF-1 promotes PCa progression in vivo. ${ }^{13}$

In 2016, a study by Zhou Feng, et al., tested the correlation between BMI and Gleason score of prostate biopsies in Chinese population. ${ }^{20}$ Two hundred and ninety patients performed biopsy, 137 were diagnosed with prostate adenocarcinoma with 70 people having a high level of BMI and 67 having a normal BMI. ${ }^{20}$ Seventeen people had a low level of Gleason score $(<7)$ and 120 people had a high level of Gleason score $(\geq 7) .{ }^{20}$ From the data test results indicate that while there was no effect of BMI on the rate of positive prostate cancer biopsies, the rate of high 


\section{Research Article}

Gleason scores was greater in the high BMI group than the normal BMI group, and it was different with the study in 2016 by Klaasen, et al., on Western and USA society that claimed obesity to be associated with higher level of Gleason score. ${ }^{11,20}$

Based on the results of this study, there are no relationship between BMI and Gleason score in Indonesian PCa patients. It is possible that in the Hasan Sadikin General Hospital, the prostate adenocarcinoma might be caused by other etiologies. The limitation of this study were limited status of body weight and height data measurement in Hasan Sadikin PCa patients and the accuracy of height measurement and weight was not properly standardized. We suggest subsequent study to do re-measurement for weight status and height of prostate adenocarcinoma patients.

\section{Conclusion}

There is no relation between BMI in Indonesian PCa and Gleason score in Hasan Sadikin General Hospital.

\section{References}

1. Mustafa M, Salih AF, Illzam EM, Sharifa AM, Suleiman M, Hussain SS. Prostate Cancer: Pathophysiology, Diagnosis , and Prognosis. IOSR J Dent Med Sci. 2016;15(6):4-11.

2. Siegel RL, Miller KD, Jemal A. Cancer statistics. CA Cancer J Clin. 2016;66(1):7-30.

3. Allott EH, Masko EM, Freedland SJ. Obesity and prostate cancer: Weighing the evidence. Eur Urol. 2013;63(5):800-9.

4. Torre LA, Sauer AM, Chen Jr. MS, Kagawa-Singer M, Jemal A, Siegel RL. Cancer statistics for Asian Americans, Native Hawaiians, and Pacific Islanders, 2016: Converging incidence in males and females. CA Cancer J Clin. 2016;66(3):182-202.

5. American Cancer Society. Cancer Facts \& Figures 2016. Cancer Facts Fig 2016. 2016;1-9.

6. Ferlay J, Steliarova-Foucher E, Lortet-Tieulent J, Rosso S, Coebergh JWW, Comber H, et al. Cancer incidence and mortality patterns in Europe: Estimates for 40 countries in 2012. Eur J Cancer. 2013;49(6):1374-403.

7. Zhang G, Zhu Y, Chen H, Han C, Liu F, Xu J, et al. Association Between the Body Mass Index and Prostate Cancer at Biopsy is Modified by Genetic Risk: A Cross-Sectional Analysis in China. Medicine (Baltimore). 2015;94(42):1-5.

8. Ikatan Ahli Urologi Indonesia untuk Komite Nasional Penanggulangan Kanker (KPKN). Panduan Nasional Penanganan Kanker Prostat. Jakarta: Kementrian Kesehatan Republik Indonesia; 2015. 1-4 p.

9. Wahidin M, Noviani R, Hermawan S, Andriani V, Ardian A, Djarir H. Population-based cancer registration in Indonesia. Asian Pac J Cancer Prev. 2012;13(4):1709-10.

10. Baade PD, Youlden DR, Cramb SM, Dunn J, Gardiner RA. Epidemiology of prostate cancer in the Asia-Pacific region. Prostate Int. 2013;1(2):47-58.

11. Klaassen Z, Howard LE, Terris MK, Aronson WJ, Cooperberg MR, Amling CL, et al. Mp53-01 the Relationship of Obesity, Pathologic Gleason Grade and Prostate Cancer Tumor Volume At the Time of Radical Prostatectomy—Results From the Search Database. J Urol. 2015;193(4):e635.

12. Goris Gbenou MC, Peltier A, Schulman CC, Velthoven R van. Increased body mass index as a risk factor in localized prostate cancer treated by radical prostatectomy. Urol Oncol Semin Orig Investig. 2016;34(6):254.e1254.e6.

13. Wargasetia TL. Memahami Kaitan Obesitas dan Kanker: Peluang untuk Pencegahan Kanker. Berk Ilm Kedokt Duta Wacana. 2016;1:3.

14. WHO | Obesity and overweight [Internet]. Guideline: Sugar intake for Adults and Children. World Health Organization; 2016 [cited 2016 Nov 25]. Available from: http://www.who.int/mediacentre/factsheets/fs 311/en/

15. eurostat. Overweight and obesity - BMI statistics [Internet]. Statistics Explained. 2016 [cited 2016 Nov 28]. Available from: http://ec.europa.eu/eurostat/statistics-explained/index.php/Overweight_and_obesity__BMI_statistics 


\section{Research Article}

16. Ogden CL, Carroll MD, Fryar CD, Flegal KM. Prevalence of Obesity Among Adults and Youth: United States, 2011-2014. NCHS Data Brief. 2015;(219):1-8.

17. Namiki M, Akaza H, Lee SE, Song J-M, Umbas R, Zhou L, et al. Prostate Cancer Working Group report. Jpn J Clin Oncol. 2012;40 Suppl 1(Supplement 1):i70-5.

18. Badan Penelitian dan Pengembangan Kesehatan. Riset Kesehatan Dasar (RISKESDAS) 2013. Lap Nas 2013. p83.

19. Kementerian Kesehatan RI. Kementerian Kesehatan Republik Indonesia [Internet]. 2012 [cited 2016 Nov 28]. Available from: http://www.depkes.go.id/article/view/15012300021/25-januari-hari-gizi-nasional.html

20. Feng Z, Xi C, Jinxian P, Jun O, Gang L, Jigen P, et al. Correlation between body mass index ( BMI ) and the Gleason score of prostate biopsies in Chinese population. Oncotarget. 2016;7(39):63338-41.

21. Rodriguez C, Freedland SJ, Deka A, Jacobs EJ, McCullough ML, Patel A V, et al. Body mass index, weight change, and risk of prostate cancer in the Cancer Prevention Study II Nutrition Cohort. Am Assoc Cancer Res. 2012;16(1):63-9.

22. Tang B, Han CT, Zhang GM, Zhang CZ, Yang WY, Shen Y, et al. Waist-hip Ratio (WHR), a Better Predictor for Prostate Cancer than Body Mass Index (BMI): Results from a Chinese Hospital-based Biopsy Cohort. Sci Rep. 2017;7:43551.

23. Zeigler-Johnson C, Morales KH, Lal P, Feldman M. The Relationship between Obesity, Prostate Tumor Infiltrating Lymphocytes and Macrophages, and Biochemical Failure. PLoS One. 2016;11(8):e0159109.

24. Barba C, Cavalli-Sforza T, Cutter J, Darnton-Hill I, Deurenberg P, Deurenberg-Yap M, et al. Appropriate bodymass index for Asian populations and its implications for policy and intervention strategies. Lancet. 2012;363(9403):157-63. 